\title{
Uji Daya Hambat Ekstrak Etanol Kulit Buah Terong Ungu (Solanum melongena L.) Terhadap Staphylococcus aureus dan Escherichia coli
}

\author{
Dewi Purnamasari", Rissa Laila Vifta, Jatmiko Susilo \\ Program Studi Farmasi, Fakultas Ilmu Kesehatan, Universitas Ngudi Waluyo \\ Jalan Gedongsongo, Candirejo, Ungaran Barat \\ *Email : dewi_purnamasari@gmail.com
}

\begin{abstract}
Abstrak
Kulit terong ungu (Solanum melongena L.) mengandung senyawa bioaktif flavonoid dan alkaloid yang dapat menghambat pertumbuhan bakteri Staphylococcus aureus dan Escherichia coli. Penelitian dilakukan dengan tujuan mengetahui aktifitas antimikroba ekstrak etanol kulit terong ungu (Solanum melongena L.) terhadap Staphyloococcus aureus dan Escherichia coli. Pengujian antibakteri dilakukan menggunakan metode sumuran dengan 5 kelompok perlakuan. Jenis penelitian adalah eksperimental murni dengan post tes control design yang menggunakan kontrol positif Ciprofloxacin, kontrol negatif Aquadest, serta tiga variasi kontrol perlakuan. Konsentrasi ekstrak yang digunakan adalah 15\%, 30\%, dan 45\% dengan pengamatan diameter zona hambat.. Data dianalisis menggunakan SPSS uji One Way ANOVA. Hasil penelitian menunjukkan peningkatan diameter zona hambat pada variasi konsentrasi 15\%, 30\%, dan 45\%. Aktifitas penghambatan yang sebanding dengan kontrol positif diperoleh pada konsentrasi $45 \%$ dengan rata-rata diameter zona hambat 2,68 $\pm 0,16 \mathrm{~cm}$

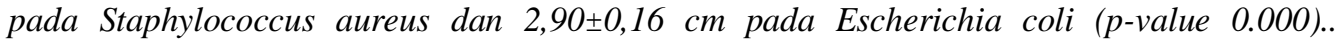
Aktifitas daya hambat ekstrak etanol kulit buah terong menunjukkan spektrum luas bakteriostatik yang mana dapat menghambat bakteri gram positif dan gram negatif.
\end{abstract}

Kata kunci: antibakteri, escherichia coli, kulit terong ungu, staphyloococcus aureus,

\section{PENDAHULUAN}

Penyakit infeksi merupakan salah satu masalah dalam bidang kesehatan yang dapat menyerang seluruh tubuh yang disebabkan oleh bakteri. Salah satu bakteri penyebab infeksi adalah Staphylococcus aureus dan Escherichia coli. Infeksi Staphylococcus aureus diasosiasikan dengan beberapa kondisi patologi diantaranya bisul, jerawat, pneumonia, dan meningitis (King, 2010), sedangkan infeksi Escherichia coli antara lain infeksi saluran kemih sebesar $90 \%$ dan peritonitis akut $50 \%$ (Green, 2011).

Staphylocccus aureus merupakan bakteri gram positif yang termasuk jenis bakteri paling kuat daya tahannya yang tidak membentuk spora dan tidak membentuk flagel (Syahrurahman, 2010). Staphylococcus aureus menyebabkan penyakit Staphylococcal scalded skin syndrom yang terjadi pada anak usia kurang dari enam tahun (King, 2010), bisul, infeksi kulit, pneumonia, Osteomielitis, Meningitis dan Endokarditis (Kusuma, 2009).

Escherichia coli merupakan bakteri gram negatif golongan mesofilik yang menyebabkan penyakit diare dengan mekanisme melalui enterotoksin dan invasi mukosa. Selain itu, Escherihia coli dapat menginfeksi saluran kemih (Brooks et al., 2007), peritonitis akut (Green, 2011), Traveler's diarrhea, meningitis dan ada pula pneumonia dan sepsis neonates.

Penggunaan obat tradisional dinilai memiliki efek samping yang lebih kecil dibandingkan dengan obat yang berasal dari bahan kimia, disamping itu harganya lebih terjangkau. Selain itu keuntungan lain penggunaan penggunaan obat tradisional adalah bahan bakunya mudah diperoleh dan harganya yang relatif murah

Beberapa penelitian terkait pemanfaatan tanaman sebagai antimikroba antara lain dilaporkan oleh (Poeloengan dan Praptiwi, 2010) yang menggunakan herba kulit manggis sebagai antibakteri, kulit batang matoa (Ngajow et $a l .$, 2013), kulit apel manalagi (Jannata et $a l$., 2014), serta kulit batang tumbuhan kasturi (Rosyidah, et al., 2010). Beberapa tanaman tersebut digunakan sebagai antibakteri karena teruji mengandung senyawa aktif flavonoid, 
alkaloid, saponin, tannin yang memiliki efek penghambatan terhadap bakteri.

Tanaman terong ungu (Solanum melongena L.) memiliki kandungan senyawa alami seperti vitamin A,B1, B2 C, D, fosfor, karetenoid, antosianin dan alkaloid. Antosianin merupakan bagian dari flavonoid yang disintesis melalui jalur fenillpropanoid yang bekerja sebagai antibakteri dengan cara menghambat ikatan protein pada membran sel sehingga membran sel menjadi lisis dan jamur tidak dapat berkembang (Sulistyawati et al., 2009).

Berdasarkan uraian tersebut dengan diketahuinya kandungan senyawa aktif pada kulit buah terong ungu (Solenummelongena L.),peneliti tertarik ingin mengetahui efektifitas ekstrak etanol kulit buah terong ungu (Solanum melongena L.) sebagai kandidat antibakteri terhadap bakteri staphylococcus aureus dan escherichia coli.

\section{METODE PENELITIAN}

\section{Alat dan Bahan}

Alat

Autoclave, oven, obyek glass, lampu spiritus, incase, cawan petri, ose steril, mikropipet, inkubator, pipet ukur steril, pipet volume, pipet tetes, batang pengaduk, dan alat-alat gelas yang disterilkan (beker glass, Erlenmeyer, tabung reaksi, labu takar, dan gelas ukur).

\section{Bahan}

Bahan uji yang digunakan adalah kulit buah terong ungu (Solanum melongena L.), yang sebelumnya telah dideterminasi di Laboratorium Biologi-MIPA Universitas Diponegoro.Suspensi bakteri Stapylococcus aureus, dan Escericia coli, aquadest, etanol 70\%, media Nutrient Agar, $\mathrm{NaCl}$ 0.9\%.

\section{Prosedur Penelitian}

\section{Jenis dan Rancangan Penelitian}

Jenis penelitian yang digunakan adalah penelitian eksperimental, dengan tujuan utama menguji coba suatu objek penelitian, kemudian dilihat diameter zona hambat ekstrak etanol kulit buah terong ungu (Solanum Melongena L) terhadap pertumbuhan bakteri Staphylococcus aureus dan Escherichia coli.

Pembuatan Ekstrak Etanol kulit buah terong ungu (Solanum Melongena L)
Menurut Goeswin (2007) Pembuatan ekstrak kulit buah terong ungu (Solanum melongena L.) diekstrak dengan metode maserasi menggunakan pelarut etanol $70 \%$. Sebanyak 500 gram kulit buah terong ungu (Solanum melongena L.) dimasukan kedalam bejana kemudian ditambah $3750 \mathrm{ml}$ etanol, ditutup dan dibiarkan selam 5 hari terlindung dari cahaya, dengan pengadukan satu kali sehari. Setelah 5 hari kemudian disaring menggunakan kertas saring dan didapatkan maserat pertama. Ampas yang didapatkan ditambahkan $1250 \mathrm{ml}$ etanol dibiarkan didalam bejana yang tertutup dan terlindung dari cahaya selama 2 hari kemudian endapan dipisahkan dan didapat hasil maserat ke-2. Setelah itu hasil maserat pertama dan kedua dicampurkan kemudian diuapkan diatas waterbath dengan temperatur $60^{\circ} \mathrm{C}$ sampai pelarut menguap sempurna sehingga diperoleh ekstrak kental kulit buah terong ungu (Solanum melongena L.).

\section{Penapisan Fitokimia}

Penapisan fitokimia dilakukan untuk mengidentifikasi senyawa flavonoid, alkaloid, tanin, dan saponin yang terkandung dalam kulit buah terong ungu (Solanum Melongena L.).

\section{1) Identifikasi Flavonoid}

Sampel ditambahkan dengann metanol sampai terendam, lalu dipanaskan kemudian ditambahkan 3 tetes $\mathrm{H}_{2} \mathrm{SO}_{4}$ pekat. Terbentuknya warna kuning, hijau, merah atau jingga menunjukan adanya flavonoid

\section{2) Identifikasi Saponin}

Identifikasi saponin dilakukan dengan uji Forth, yaitu dengan diamati pembentukan buih.

\section{3) Identifikasi Tanin}

Identifikasi tanin dilakukan dengan metode Ferri Klorida yaitu dengan meneteskan larutan besi (III) klorida $1 \%$ ke dalam larutan cuplikan yang menimbulkan warna hijau, merah, ungu, biru, atau hitam yang kuat.

\section{4) Identifikasi Alkaloid}

Uji alkaloid dilakukan dengan menggunakan pereaksi mayer dan dikocok. Alkaloid dianggap positif jika timbul endapan berwarna putih.

\section{Pembuatan Larutan Ciprofloxacin}


Ciprofloxacin digunakan sebagai larutan pembanding yaitu sebagai kontrol positif sedangkan kontrol negatifnya digunakan aquadest. Pembuatan stok awal ciprofloxacin 1 mg yang setara dengan konsentrasi $1000 \mu \mathrm{g} / \mathrm{ml}$. Kemudian dibuat pengenceran untuk masingmasing bakteri. Dosis invitro untuk bakteri gram positif yaitu $4 \mu \mathrm{g} / \mathrm{ml}$ dan untuk gram negatif yaitu $2 \mu \mathrm{g} / \mathrm{ml}$.

\section{Pembuatan Suspensi dan Identifikasi Bakteri Staphylococcus Aureus dan E.coli} Bakteri Staphylcoccus aureus dan Escherichia coli diambil beberapa koloni dari biakan induk menggunakan ose steril, disuspensikan pada media $\mathrm{Na}$ steril, kemudian diinkubasi pada suhu $37^{\circ} \mathrm{C}$ selama 24 jam. Suspensi bakteri diambil $100 \mu \mathrm{l}$ pada hari pertama dimasukkan dalam $1 \mathrm{ml} \mathrm{Na}$, kemudian diinkubasi $37^{\circ} \mathrm{C}$ selama 5 jam. Setelah itu diambil $100 \mu \mathrm{l}$, disamakan konsentrasinya dengan cara menambah larutan salin (Aquadest) sedikit demi sedikit karena sebagai larutan pengisotonis agar tekanan osmosis antara larutan dan mikroba sama sehingga mempunyai kekeruhan yang sesuai dengan standart Mc. Farland $\left(10^{8} \mathrm{CFU} / \mathrm{ml}\right)$.

Pengujian Antibakteri Ekstrak kulit buah terong ungu (Solanum Melongena $L$ )

Uji aktivitas antibakteri dilakukan dengan metode difusi sumuran seperti yang dicantumkan pada Gambar 1. Pengujian dilakukan pada ekstrak kulit buah terong ungu (Solanum melongena L.) pada tiga konsnetrasi yang berbeda, yakni $15 \%, 30 \%$, dan $45 \%$. Masing-masing konsentrasi dilakukan pengujian terhadap Staphylococcus aureus dan Escherichia coli, mula-mula media Na dituang dalam cawan petri dibiarkan dingin kemudian ditambahkan suspensi bakteri dicampur dan digoyang-goyang sampai merata dan dibiarkan memadat kemudian media dilubangi menggunakan ring (sumuran) dan diteteskan ekstrak etanol kulit buah terong ungu tunggu hingga padat. Selanjutnya diinkubasi selama 24 jam pada suhu $37^{\circ} \mathrm{C}$.

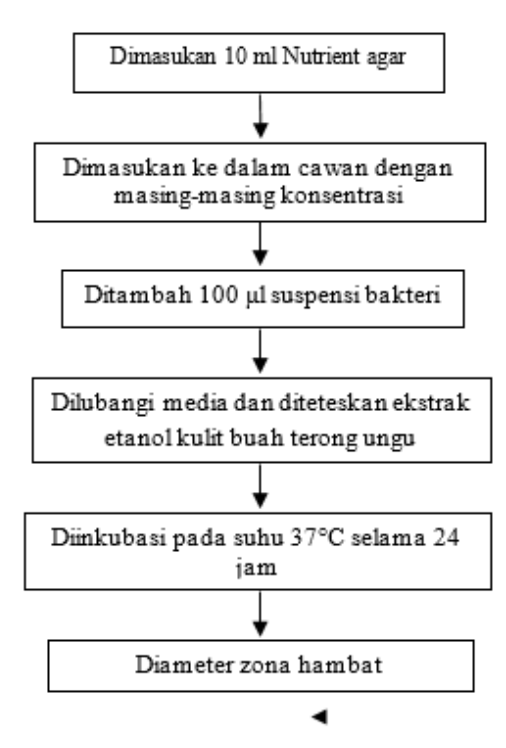

Gambar 1. Bagan alur pengujian antibakteri
ekstrak etanol kulit buah terong ungu

\section{Analisis Data}

Analisis data penelitian secara statistik dengan menggunakan SPSS (Statistical Product and Service Solutions) versi 16 didahului dengan uji normalitas menggunakan rumus dari Shapiro-Wilk dan uji homogenitas menggunakan rumus dari Lavene Test. Kemudian, data dianalisis dengan statistik parametik Anava satu jalan dan dilanjutkan dengan uji LSD.

\section{HASIL DAN PEMBAHASAN \\ Determinasi Tanaman}

Determinasi merupakan proses dalam menentukan nama atau jenis tumbuhan secara spesifik. Determinasi tanaman terong ungu (Solanum melongena L.) dilakukan di Laboratorium Ekologi dan Biosistematika Jurusan Biologi Fakultas Sains dan Matematika Universitas Diponegoro Semarang.

Determinasi dilakukan dengan tujuan untuk mendapatkan kebenaran dari tanaman yang akan diteliti, dan menghindari kesalahan dalam pengumpulan bahan utama yang kemungkinan tercampur dengan tanaman lain. Hasil determinasi tanaman terong ungu dinyatakan sebagai berikut.

$\begin{array}{ll}\text { Kingdom } & \text { : Plantae } \\ \text { Divisi } & \text { : Spermatophyta } \\ \text { Sub Divisi } & : \text { Angiospermae } \\ \text { Class } & : \text { Magnoliopsida } \\ \text { Ordo } & \text { : Solanales } \\ \text { Family } & : \text { Solanaceae }\end{array}$


Genus : Solanum

Spesies : Solanum Melongena L

Nama binomial : Solanum Melongena L

\section{Penapisan Fitokimia}

Penapisan fitokimia dilakukan secara kualitatif untuk mengidentifikasi senyawa aktif yang terkandung dalam ekstrak etanol kulit terong ungu (Solanum Melongena L.). Hasil skrining fitokimia pada Tabel 1 menunjukkan bahwa Ekstrak etanol kulit terong ungu (Solanum melangena L.) mengandung flavonoid dan alkaloid.

Tabel 1. Hasil Penapisan Fitokimia ekstrak etanol kulit terong ungu (Solanum Melongena L.)

\begin{tabular}{lll}
\hline Uji Fitokimia & Hasil & Kesimpulan \\
\hline Flavonoid & $\begin{array}{l}\text { Terbentuk warna } \\
\text { merah }\end{array}$ & Positif \\
\end{tabular}

\begin{tabular}{lll}
\hline Alkaloid & $\begin{array}{l}\text { Terbentuk endapan } \\
\text { putih }\end{array}$ & Positif \\
\hline Tanin & $\begin{array}{l}\text { Tidak ada } \\
\text { perubahan warna }\end{array}$ & Negatif \\
\hline Saponin & $\begin{array}{l}\text { Tidak terbentuk } \\
\text { buih mantap }\end{array}$ & Negatif \\
\hline
\end{tabular}

Pada identifikasi senyawa flavonoid menggunakan pereaksi $\mathrm{H}_{2} \mathrm{SO}_{4}$. Hasil yang diperoleh pada ekstrak kulit terong ungu adalah positif mengandung senyawa flavonoid ditandai dengan munculnya merah bata. Terbentuknya warna merah karena penambahan $\mathrm{H}_{2} \mathrm{SO}_{4}$ pekat dan metanol mengakibatkan terjadinya reaksi substitusi elektrofilik yang menghasilkan kalkon (Pakaya et al., 2015).

Identifikasi Alkaloid dilakukan dengan menambahkan pereaksi mayer dan dikocok. Timbul endapan warna putih sehingga dianggap positif mengandung alkaloid. Terjadinya endapan putih disebabkan karena pereaksi mayer berikatan dengan alkaloid melalui ikatan kooordinasi atom $\mathrm{N}$ alkaloid dan $\mathrm{Hg}$ menghasilkan senyawa kompleks merkuri yang non polar.

\section{Hasi Uji Daya Hambat Ekstrak Etanol Kulit Terong Ungu (Solanum melongena L.)}

Uji daya hambat dilakukan terhadap Staphylococcus aureus dan Eschericha coli. Bakteri Staphylococcus aureus dipilih karena merupakan bakteri gram positif dan Eschericha coli merupakan bakteri gram negatif yang sering menyebabkan penyakit seperti diare dan infeksi kulit (Levinson, 2008). Pengujian daya hambat dilakukan menggunakan metode difusi sumuran dengan pengamatan diameter zona hambat sebagai indikator penghambatan bakteri. Hasil uji antibakteri disajikan pada Tabel 2 dan 3.

Tabel 2. Hasi uji daya hambat ekstrak etanol kulit terong ungu (Solanum melongena L.) terhadap pertumbuhan S.aureus

\begin{tabular}{lll}
\hline $\begin{array}{l}\text { Kelompok } \\
\text { Perlakuan }\end{array}$ & Mean & SD \\
\hline Kontrol Positif & 2,78 & 0,19 \\
Konsentrasi 15\% & 1,30 & 0,16 \\
Konsentrasi 30\% & 2,28 & 0,24 \\
Konsentrasi 45\% & 2,68 & 0,16 \\
\hline
\end{tabular}

Tabel 3. Hasi uji daya hambat ekstrak etanol kulit terong ungu (Solanum melongena L.) terhadap pertumbuhan E.coli

\begin{tabular}{lll}
\hline Kelompok & Mean & SD \\
Perlakuan & 3,10 & 0,35 \\
\hline Kontrol Positif & 1,46 & 0,11 \\
Konsentrasi 15\% & 2,46 & 0,21 \\
Konsentrasi 30\% & 2,90 & 0,16 \\
\hline Konsentrasi 45\% &
\end{tabular}

Kemampuan antibakteri pada daun Sirih Hijau dipengaruhi oleh kandungan senyawa metabolit sekunder yang terkandung pada ekstrak. Flavonoid pada kulit terong ungu (Solanum melongena L.) merupakan senyawa polar yang mudah larut dalam pelarut yang polar seperti air, etanol dan metanol (Suryani, 2014). Flavonoid juga memiliki aktivitas yang beragam salah satunya sebagai antibakteri dengan cara mendenaturasi ikatan protein pada membran sel, sehingga membran sel menjadi lisis dan jamur tidak dapat berkembang. (Cowan, 1999).

Senyawa aktif lain dalam ekstrak kulit terong ungu yang memiliki aktifitas antibakteri adalah alkaloid. Senyawa alkaloid dalam penelitian ini berfungsi sebagai antibakteri dengan cara dengan cara mengganggu komponen penyusun peptidoglikogen pada sel bakteri, sehingga lapisan dinding sel tidak terbentuk secara utuh dan menyebabkan kematian sel dan menghambat replikasi DNA itu sendiri, akibatnya terjadi gangguan replikasi DNA yang menyebabkan kematian sel. (Cushine et al., 2014).

\section{Analisis Statistik}

Data uji daya hambat terhadap S.aureus dan E.coli selanjutnya dianalisis normalitas 
menggunakan Shapiro-Wilk yang menunjukkan nilai p-value lebih dari 0.05 yang berarti data terdistribusi normal, kemudian dilanjutkan dengan uji Anava. Hasil uji Anava menunjukkan nilai p-value kurang dari 0.05, sehingga uji dapat dilanjutkan menggunakan uji LSD (Tabel 4 dan 5) untuk mengetahui perbedaan pada masing-masing kelompok perlakuan.

Tabel 4. Uji LSD pada Staphylococcus aureus

\begin{tabular}{lll}
\hline $\begin{array}{l}\text { Pasangan } \\
\text { Perlakuan }\end{array}$ & $\begin{array}{l}\text { p- } \\
\text { value }\end{array}$ & Kesimpulan \\
\hline KP vs K15\% & 0,000 & Berbeda signifikan \\
\hline KP vs K30\% & 0,001 & Berbeda signifikan \\
\hline KP vs K 45\% & 0,420 & Berbeda tidak signifikan \\
\hline K15\% vs K30\% & 0,000 & Berbeda signifikan \\
\hline K15\% vs K45\% & 0,000 & Berbeda signifikan \\
\hline K 30\% vs K45\% & 0,004 & Berbeda signifikan \\
\hline
\end{tabular}

Tabel 5. Uji LSD pada Escherichia coli

\begin{tabular}{|c|c|c|c|}
\hline $\begin{array}{l}\text { Pasangan } \\
\text { Perlakuan } \\
\end{array}$ & $\begin{array}{l}\text { p- } \\
\text { value }\end{array}$ & Kesimpulan & $\begin{array}{l}\text { Ekstrak etanol kulit terong ungu memiliki } \\
\text { aktifitas dengan spektrum luas yang bersifat }\end{array}$ \\
\hline KP vs 1 & 00 & rbe & bakteriostatik pada penghambatan bakteri \\
\hline $\mathrm{KP}$ & & ro & Staphylococcus aureus dan Escherichia coli. \\
\hline KP vs K & 183 & iifikan & ak etanol kulit terong ungu konsentrasi \\
\hline K15 & 000 & erbe & ada bakteri S.aureus 1,30 \\
\hline $\mathrm{K} 159$ & & & $1,46 \pm 0,11 \mathrm{~cm} ;$ konsentrasi \\
\hline K $30 \%$ vs K $45 \%$ & 0,007 & & \\
\hline & & & $16 \mathrm{~cm}$. \\
\hline
\end{tabular}
kontrol positif (Ciprofloxacin) yang artinya konsentrasi $15 \%$ dan 30\% memiliki aktivitas sebagai antibakteri namun efeknya tidak sebanding dengan kontrol positif, sedangkan pada konsentrasi $45 \%$ berbeda tidak signifikan yang artinya pada konsentrasi $45 \%$ efeknya sebanding dengan kontrol positif baik terhadap S.aureus maupun E.coli.

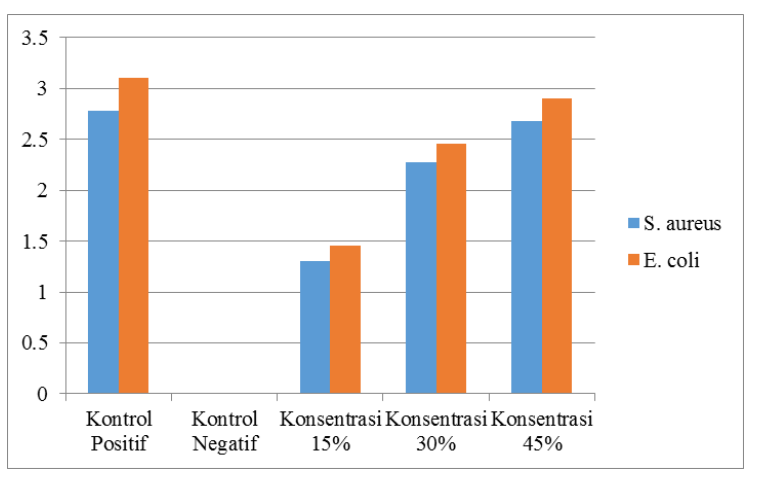

Gambar 2. Perbandingan daya hambat ekstrak etanol kulit terong ungu terhadap pertumbuhan S.aureus dan E.coli

Perbandingan aktifitas daya hambat pada masing-masing konsentrasi $(15 \%, 30 \%$, dan 45\%) memiliki perbedaan yang signifikan baik pada penghambatan S.aureus maupun E.coli. semakin tinggi konsentrasi ekstrak, aktifitas daya hambat semakin meningkat. Hal ini karena semakin banyak senyawa aktif yang terkandung didalamnya. Peningkatan aktifitas tersebut menunjukkan bahwa ekstrak etanol kulit terong ungu memiliki spektrum luas penghambatan bekteri yakni pada bakteri gram positif dan negatif.

\section{KESIMPULAN}

Berdasarkan hasil penelitian yang suđah dilakukan tentang uji daya hambat ekstrak etanol kulit terong ungu (Solanum melongena L.) dapat disimpulkan bahwa Ekstrak etanol kulit terong ungu memiliki aktifitas dengan spektrum luas yang bersifat bakteriostatik pada penghambatan bakteri Staphylococcus aureus dan Escherichia coli. Ekstrak etanol kulit terong ungu konsentrasi $15 \%$ pada bakteri S.aureus $1,30 \pm 0,16 \mathrm{~cm}$ dan E.coli $1,46 \pm 0,11 \mathrm{~cm}$; konsentrasi $30 \%$ S.aureus konsentrasi $45 \%$ S.aureus 2,68 $\pm 0,16$ dan E.coli $2,90 \pm 0,16 \mathrm{~cm}$

\section{DAFTAR PUSTAKA}

Brooks. G.F. Janet. S.B. Stephen. A.M. 200. Jawetz, Melinck, Adelberg Mikrbiologi Kedokteran. Edisi 23. Alih bahasa Hartono et al. Jakarta : EGC.

Cushine. T.P. Benjamart. Lamb. J.A. 2014. Alkaloids An Overview Of their Antibacterial Antibiotic-enhaching and Antivirulance Activities. International Journal Of Antimicrobial Agents. 381383

Cowan. M.M. 1999. Plant Products as antimicrobial agents. Clinical Microbiology Reviews, Vol. 12 (4). Hal. 564-582

Green. T.E. 2011. Spontaneous Bacterial Peritonitis. (diunduh dari Juni 2012).

Jannata, R.H., Gunadi, A, dan Ermawati, 2014. Daya Antibakteri Ekstrak Kulit Apel Manalagi (Malus sylvestris Mill.) Terhadap Pertumbuhan Streptococcus 
mutans. e-Jurnal Pustaka Kesehatan, Vol. 2, No.1, Hal 23-28

King. R.W. 2010. Staphylococcus Scalded Skin Syndrome in Emergency Medicine. (diunduh dari http://emedicine.medscape.com/article/7 89105-verview\#aw2aab6b2b3aa Juni 2012).

Kusuma. S,A,F. 2009. Staphylococcus aureus. UNPAD.

Levinson W. 2008. Review Of Medical Microbiology. America: The McGrawHill Companies.: 25-26, 78-79.

Ngajow, M., Abidjulu, J, Kamu, V.S. 2013. Pengaruh Antibakteri Ekstrak Kulit Batang Matoa (Pometia pinnata) terhadap Bakteri Staphylococcus aureus secara In vitro. Jurnal Mipa Unsrat Online, Vol. 2, No.2, Hal. 128-132.

Pakaya W, et al. 2015. Analisis Kadar Flavonoid Dari Ekstrak Metanol Daun Dan Bunga Tembelekan. Universitas Negeri Gorontalo.

Poeloengan, M., dan Praptiwi. 2010. Uji Aktivitas Antibakteri Ekstrak Kulit Buah Manggis (Gardnia mangostana Linn). Media Litbang Kesehatan, Vol. 20, No.2, Hal 65-69.

Rosyidah, K., Nurmuhaimina, S.A., Komari, N., dan Asturi, M.D. 2010. Aktifitas Antibakteri Fraksi Saponin Dari Kulit Batang Tumbuhan Kasturi (Mangifera casturi). Alchemy. Vol. 1, No.2, Hal : 65-69

Suryani, dkk. 2014. Uji Aktivitas Tabir Surya Formula Sediaan Losio Ekstrak Metanol Daun Mangkokan (Nothophanax scutellarium Merr.), Medula. Vol. 2. No. 1, Hal : 126-130.

Syahrurachman A. dkk. 2010. Buku ajar mikrobiologi kedokteran. Jakarta. Binarupa Aksara Publisher. 